\title{
THE EX ANTE AUCTION MODEL FOR THE CONTROL OF MARKET POWER IN STANDARD SETTING ORGANIZATIONS
}

\author{
Damien Geradin, Anne Layne-Farrar \\ and $A$. Jorge Padilla
}

CEMFI Working Paper No. 0703

May 2007

CEMFI

Casado del Alisal 5; 28014 Madrid

Tel. (34) 914290 551. Fax (34) 914291056

Internet: www.cemfi.es

Damien Geradin is a Partner at Howrey LLP and a Professor of Competition Law and Economics and a member of TILEC at Tilburg; Anne Layne-Farrar is Director at LECG Consulting. Jorge Padilla is Managing Director at LECG Consulting and Research Fellow at CEMFI and CEPR. We wish to thank Nadia Hussaini and Kylie Canaday for research assistance. Financial support from Qualcomm is gratefully acknowledged. The ideas and opinions in this paper are exclusively our own. 
CEMFI Working Paper 0703

May 2007

\title{
THE EX ANTE AUCTION MODEL FOR THE CONTROL OF MARKET POWER IN STANDARD SETTING ORGANIZATIONS
}

\begin{abstract}
RAND commitments-i.e., promises to license on reasonable and non-discriminatory termsplay a key role in standard setting processes. However, the usefulness of those commitments has recently been questioned. The problem allegedly lies in the absence of a generally agreed test to determine whether a particular license satisfies a RAND commitment. Swanson and Baumol have suggested that "the concept of a 'reasonable' royalty for purposes of RAND licensing must be defined and implemented by reference to ex ante competition." In their opinion, a royalty should be deemed "reasonable" when it approximates the outcome of an ex ante auction process where IP owners submit RAND commitments coupled with licensing terms and selection to the standard is based on both technological merit and licensing terms. In this paper we investigate whether the ex ante auction approach proposed by Swanson and Baumol is likely to deliver efficient outcomes, both from static and dynamic standpoints. We find that given the peculiar characteristics of some of the industries where standardization takes place, in particular the many different business models adopted by innovating companies in those industries, the ex ante auction approach proposed by Swanson and Baumol may not always deliver the right outcomes from a social welfare viewpoint.
\end{abstract}

Damien Geradin

Howrey LLP

GeradinD@howrey.com
Anne Layne-Farrar

LECG

alayne-farrar@lecg.com
A. Jorge Padilla

LECG

jpadilla@lecg.com 


\section{INTRODUCTION}

The adoption of proprietary technologies by standard-setting organizations (SSOs) is often necessary to ensure that the resulting standard provides the greatest possible value to its users and, therefore, to guarantee the success of the standardization process. However, some claim that the selection of proprietary technologies as standards may also create significant market power, generate returns in excess of those needed to remunerate innovation, distort competition and restrict the dissemination of new and superior technologies. A necessary (but not sufficient) condition for the creation of ex post (i.e., attributable to the standard selection) market power is the absence of alternative technologies that can be substituted for the selected technology at comparable user costs. ${ }^{2}$ When such alternative technologies are available, an SSO's endorsement of a proprietary technology as a standard may result in a reduction of (short-term) competition in the technology market. Otherwise, the selection process will have no adverse effect on technological competition.

SSOs typically request the owners of technologies selected to be part of the standard to commit to license their intellectual property (IP) on reasonable and nondiscriminatory (RAND) terms. There is a dispute about what a RAND commitment means in practice. Some authors argue that it simply represents a commitment to negotiate in "good faith" with all potential licensees. ${ }^{3}$ Others interpret a RAND commitment as a waiver by an essential IP holder of its right to seek injunctive relief in case of patent infringement. ${ }^{4}$ Some companies and their advisors have gone as far

\footnotetext{
2 See Daniel G. Swanson \& William J. Baumol, Reasonable and Nondiscriminatory (RAND) Royalties, Standards Selection, and Control of Market Power, 73 ANTITRUST L. J. 1, 51-56 (2005); Anne Layne-Farrar, A. Jorge Padilla, \& Richard Schmalensee Pricing Patents for Licensing in Standard Setting Organisations: Making Sense of FRAND Commitments (Working Paper, Oct. 2006), available at $\mathrm{http}: / / \mathrm{ssrn} . \mathrm{com} / \mathrm{abstract}=937930$.

${ }^{3}$ See Damien Geradin \& Miguel Rato, Can Standard-Setting Lead to Exploitative Abuse? A Dissonant View on Patent Hold-Up, Royalty Stacking and the Meaning of FRAND (Working Paper, Nov. 2006). available at http://ssrn.com/abstract=946792, forthcoming in EUR. COMP. J. (2007).

${ }^{4}$ Joseph Scott Miller, Standard Setting, Patents, and Access Lock-In: RAND Licensing and the Theory of the Firm, IND. L. REV., forthcoming 2007.
} 
as suggesting that a RAND promise constitutes a commitment to set royalty terms in proportion to the number of essential patents reading on a standard. ${ }^{5}$

The first interpretation - a commitment to negotiate in good faith - has been criticised as too imprecise. ${ }^{6}$ The critics of this interpretation argue that a RAND commitment may be of limited value unless it is clear to both licensors and licensees "the concrete terms or range of terms that are deemed to be reasonable and nondiscriminatory." 7 This view has been recently questioned by Lichtman (2006), who explains why some degree of imprecision may be efficient. ${ }^{8}$

We have shown elsewhere that the last two interpretations are unfounded and would lead to inefficient outcomes. ${ }^{9}$ Interpreting a RAND commitment as a binding promise not to seek injunctive relief would represent a major departure from current practice and would drastically diminish not only the ex post but also the ex ante bargaining power of IP holders creating the risk of under-compensation and underinvestment. Under this interpretation, therefore, a RAND commitment would be disproportionate and inefficient. Finally, "numerical proportionality" ignores the fact that patent values are radically different and, consequently, it would tend to overremunerate IP holders with relatively worthless patents at the expense of those others with more valuable IP. ${ }^{10}$ The adoption of a numerical proportionality rule would thus be both economically inefficient and unfair.

In a paper recently published in this journal, Daniel G. Swanson and William J. Baumol have proposed a solution to the potential for ex post market power for technologies selected by standard-setting organisations. They propose that "the

5 See, e.g., Nokia Q3 2006 Earnings Call Transcript (Oct. 19, 2006), available at http://seekingalpha.com/article/18841; Philippe Chappatte, Standard Setting and Patent Pools - Their implications for EU Competition Law, Presentation at the IBC Intellectual Property, Competition Law Conference (June 8, 2006), slide 6.

${ }^{6}$ M. Howard Morse, Standard Setting and Antitrust: the Intersection between IP Rights and the Antitrust Laws, IP LiTIGATOR (2003).

${ }^{7}$ Swanson \& Baumol, supra note 2, at 5.

${ }^{8}$ Doug Lichtman, "Patent Holdouts in the Standard-Setting Process," Academic Advisory Council Bulletin 1.3 (May 2006).

${ }^{9}$ Geradin \& Rato, supra note 3. Damien Geradin, Standardization and Technological Innovation: some reflections on ex-ante licensing, FRAND and the proper means to reward innovators, 29 WORLD COMP. 511, 527-28 (2006).

${ }^{10} \mathrm{Id}$. 
concept of a 'reasonable' royalty for the purposes of RAND licensing must be defined and implemented by reference to ex ante competition." In sharp contrast to some authors, ${ }^{11}$ Swanson and Baumol "rule out defining a reasonable RAND royalty as the royalty that would be observed in the event that the prospective licensees were to band together (either before or after standard selection) and act as a buyers' cartel."12 Such a cartel would raise a host of problems, including undercompensation for patent holders as IP buyers pressed for unfairly low licensing terms. Instead, they propose that SSOs conduct ex ante auctions of their standards. IP owners would submit RAND commitments coupled with licensing terms and the selection process would be based on technological merit and licensing terms.

For Swanson and Baumol a "reasonable" royalty for RAND purposes "is or approximates the outcome of an auction-like process appropriately designed to take lawful advantage of the state of competition ex ante ... between and among available IP options."13 This definition requires some explanation. First, as noted already, according to Swanson and Baumol a RAND promise is meant to "take lawful advantage" of ex ante competition and, as a result, is totally incompatible with the operation of a buyers' cartel ex ante. Second, Swanson and Baumol explicitly acknowledge that their proposed definition only makes sense in circumstances where there are several "available IP options"- that is, when there is competition ex ante among feasible substitute technologies so that selection to the standard may create market power ex post. This means that auctions will not be of help in potentially many cases. Lastly, but not less importantly, Swanson and Baumol recognise that the ex ante auction process needs to be "appropriately designed" to ensure that it produces reasonable results. Not every auction-like process may do the job from a RAND standpoint. In fact, they suggest the adoption of the so-called "sealed bid"

\footnotetext{
${ }^{11}$ See, e.g., Robert Skitol, Concerted Buying Power: Its Potential for Addressing the Patent Holdup Problem in Standard-Setting, 72 Antitrust L. J. 727 (2005); Gil Ohana, Marc Hansen, \& Omar Shah, Disclosure and Negotiation of Licensing Terms Prior to Adoption of Industry Standards: Preventing Another Patent Ambush, 24 EUR. COMP. L. R. 644 (2003).

${ }^{12}$ Swanson \& Baumol, supra note 2, at 13. Emphasis added.

${ }^{13} I d$., at 57. This definition has been adopted by the FTC in "Opinion of the Commission on Remedy," In the Matter of Rambus, Inc., Docket No. 9302, at 17.
} 
auction model, ${ }^{14}$ where IP owners would simultaneously submit best and final offers. The winning IP holder is the one which offers the best technology-price proposition.

In this paper we will focus on this last aspect of the Swanson and Baumol proposed definition of RAND licensing terms. Is the auction-like process proposed by these authors likely to yield efficient outcomes? That is, is it likely to compensate innovators and hence preserve the incentives to invest and innovate in new technologies? Is it likely to keep the cost of the selected technologies under control so as to ensure their optimal diffusion ex post? And lastly, would SSOs using ex ante auctions select the most efficient technologies, i.e., those that create most value for their users at a reasonable cost?

We show that Swanson and Baumol's emphasis on the design of the auction process is justified. Given the peculiar characteristics of the industries where standardization takes place (telecoms, semi-conductors, audio-visual, etc.) as well as the many different business models adopted by companies in those industries, some auction formats (e.g., a sealed-bid auction) may be preferable to others (e.g. an open ascending auction) in an economic sense. Unfortunately, however, no auction format-including the sealed-bid auction proposed by Swanson and Baumol-is likely to yield efficient outcomes once the specific characteristics of these industries and the asymmetric nature of the companies that operate in them is fully taken into account.

For example, regardless of its design an ex ante auction may produce inefficient results when the competing technologies are in the hands of both vertically integrated and non-integrated companies. We show that the dual role of vertically integrated companies in the standard setting process-innovators and users-places them at a competitive advantage in the auction process. These companies may afford setting very low royalty rates because they have the option to fund their investment with downstream profits. This advantage leads to a number of results. First, SSOs may end up selecting the technologies owned by vertically

${ }^{14} I d$. at 17 . In a sealed bid auction, all bidders simultaneously submit bids so that no bidder knows the bid of any other participant. The highest bidder pays the price it submitted. 
integrated companies even if those technologies are not the most valuable. Second, non-integrated companies may have to bid very low to match the terms offered by their vertically integrated counterparts which may reduce their incentives to innovate and participate in the cooperative standardization process. Nor do the low rates set by vertically integrated firms guarantee low downstream prices. Third, non-integrated companies may be forced to exit the relevant innovation market.

This is not the only problem we encounter. Ex ante standards auctions like those proposed by Swanson and Baumol may suffer from the so-called "winner's curse" 15 and hence under-compensate innovation. They may also facilitate predation and collusion in technological markets (since these auctions are bound to be repeated over time given the dynamic nature of innovation and standardization). And, in any event, they are likely to perform poorly when technologies are complex and there is incomplete information about the value of each alternative. ${ }^{16}$ In those circumstances, bilateral communication between buyers and sellers is important to assess the different technological options available to the standard. ${ }^{17}$ The rigidities of the auction process may stifle such valuable communication. ${ }^{18}$

The analytical framework developed by Swanson and Baumol provides useful guidance on the meaning of RAND licensing. We concur with their claim that concerns about the opportunistic exploitation of ex post market power "will be magnified if the IP owner is also a participant in the downstream market" ${ }^{\text {"19 }}$ and with their suggestion that a "non-discriminatory" license fee should satisfy the "efficient

${ }^{15}$ The "winner's curse" is a term used to describe a phenomenon in common-value auctions and bidding behavior. When a bidder wins an auction, it suggests that other bidders had lower valuations, indicating that the winning bid is very likely to be an overbid, resulting in an expected loss. See Paul D. Klemperer, Using and Abusing Economic Theory-Lessons from Auction Design, 1(2-3) J. EUR. ECON. Ass'N 272 (2003). See also, Gary Charness \& Dan Levin, The Origin of the Winner's Curse: A Laboratory Study (Working Paper, Jan. 24, 2005). The first formal claim of the "winner's curse" was made by three petroleum engineers in their analysis of oil industry auctions. See E.C. Capen, et al., Competitive Bidding in High-Risk Situations, 23 J. Petroleum TeCh. 641 (1971).

${ }^{16}$ Patrick Bajari, Robert McMillan, \& Steven Taddelis, Auctions versus Procurement: An Empirical Analysis, (Stanford Univ., Working Paper, 2004).

${ }^{17}$ Geradin \& Rato, supra note 3.

${ }^{18}$ Bajari et. al., supra note 16.

${ }^{19}$ Swanson \& Baumol, supra note 2, at 23. 
component pricing rule" (ECPR). ${ }^{20}$ We also agree with some of the qualitative implications of their approach to defining "reasonable" royalties, namely that reasonable license fees "must contribute to coverage of this constant stream of $[R \& D]$ costs and offer a profit incentive" ${ }^{, 21}$; that the level of the reasonable royalty rate "will depend directly on the extent or degree of ex ante competition"22 (i.e., on whether or not significant substitutes exist); and that reasonable royalties would not be "uniform and identical across all fields of use, territories, and customers." ${ }^{23} \mathrm{We}$ also have used their approach to explain why patents covering technologies with a greater contribution to the value of the standard and without close substitutes before the standard gets adopted should receive higher royalty payments after the adoption of the standard. ${ }^{24}$

However, we are concerned with the practical application of their definition of RAND royalties as those that equate or approximate the outcome of ex ante auctions operated by SSOs. While we see merit in the claim that "the concept of a 'reasonable' royalty for purposes of RAND licensing can be defined and implemented by reference to ex ante competition", ${ }^{25}$ we do not agree with Swanson and Baumol's contention that the ex ante auction model provides an analytical benchmark for what constitutes a reasonable royalty. ${ }^{26}$ Ex ante auctions may not lead to efficient outcomes, may facilitate collusion and predation and will not be easy to implement in practice. Furthermore, we caution against the mechanic application of an ex ante benchmark by SSOs, courts and competition authorities, who should keep in mind that the existence of alternative technologies ex ante is only one of the many factors that could be taken into account in valuing patents ex post. That is, ex ante competition relates to just one of the fifteen relevant factors in calculating a

\footnotetext{
${ }^{20} \mathrm{Id}$

${ }^{21} \mathrm{Id}$.

${ }^{22} I d$.

${ }^{23} I d$.

${ }^{24}$ Anne Layne-Farrar et al., supra note 2. This paper shows that the same property is obtained in a very different model (the Shapley value model) where equality is emphasized over efficiency.

${ }^{25}$ Swanson \& Baumol, supra note 2, at 10.

${ }^{26}$ Note that ex ante auctions can be viewed in two distinct ways: first as a prescription for SSOs, where auctions will be held to determine the IP contributors to a standard and second as a thought experiment that provides a benchmark for an ex post RAND evaluation of licensing terms.
} 
reasonable royalty for the purposes of determining damages identified in GeorgiaPacific. ${ }^{27}$ Moreover, there are many legitimate reasons why ex post licensing terms may be higher than ex ante terms - e.g., dynamic pricing, dissipation of uncertainty regarding the commercial value of the technology, etc. While evidence that ex post and ex ante terms coincide can be taken as proof of compliance for RAND purposes, the opposite is not necessarily true.

The remainder of this paper proceeds as follows. In section II we provide a brief description of the Swanson-Baumol ex ante auction model. Section III investigates the efficiency implications of this model and explains why it fails to provide a valid and workable plan or benchmark for the determination of "reasonable" royalties in the context of RAND commitments. Section IV considers the IP policies of two SSOs_-VITA and IEEE — and explains why they suffer from the same problems of the ex ante auction model. Section V concludes with a few constructive proposals.

\section{THE SWANSON-BAUMOL EX ANTE AUCTION}

As noted in the Introduction, Swanson and Baumol maintain that the outcome of an auction in which the owners of competing technologies bid for selection into the standard through the submission of RAND commitments coupled with representative licensing terms provides a plan or at least an ex post benchmark for what a reasonable royalty should be.

These auctions would be conducted by SSOs under three assumptions: (1) there would be no collective royalty negotiations with bidders after a bid has been submitted; ${ }^{28}$ (2) SSOs would select the winning bid by means of a decision-making (e.g., a voting) process that is not susceptible of being manipulated or biased by one

\footnotetext{
${ }^{27}$ Georgia-Pacific Corp. V. U.S. Plywood Corp., 318 F. Supp. 1116 (S.D.N.Y. 1970). Factor 9 states: "The utility and advantages of the patent property over the old modes or devices, if any, that had been used for working similar results."

${ }^{28}$ Swanson \& Baumol, supra note 2, at 17.
} 
or more SSO members; ${ }^{29}$ and (3) all parties would remain free to contract privately outside the standard-setting process and participation by potential licensors would be purely voluntary. ${ }^{30}$ These assumptions, Swanson and Baumol claim, ensure that the outcome of these auctions would differ materially from the outcome of a potentially unlawful and probably economically inefficient joint negotiation.

Swanson and Baumol illustrate the operation of the auction mechanism by means of a simple model where, crucially, none of the bidders produce final products-i.e., there are no vertically-integrated bidders (i.e., firms that both own patents under consideration and produce downstream products). In this simplified scenario there are two competing technologies, $\mathrm{A}$ and $\mathrm{B}$, with different cost implications for downstream firms. The best IP option is A: it would result in downstream production costs of 5 per unit of output. Using technology B would lead to downstream production costs of 6 per unit of output. Under the assumption that licensing involves no recurring costs for the patent holder, and that both bidders know the cost reductions to producers that can be achieved with each technology (and which may or may not be passed on to consumers), bidder A should be expected to win the auction commanding a license fee of 1 .

The outcome of this auction replicates ex post the outcome of unrestrained competition ex ante: the expected outcome of the Swanson-Baumol auction will be the selection of the best IP option at a fee equal to the recurring costs of licensing plus the difference in value between the best and next-best IP alternatives. As rival technologies come closer to being perfect substitutes, the competitive royalty will approximate the incremental cost of licensing ( 0 in the simplified example). ${ }^{31}$

\footnotetext{
${ }^{29}$ Id. at 17 .

${ }^{30} \mathrm{Id}$. at 17.

${ }^{31}$ This simple one period model abstracts away the question of incentives for follow on research, which would be detrimentally affected if royalties provide an insufficient return on R\&D investments.
} 


\section{ASSESSING THE EX ANTE AUCTION MODEL}

Swanson and Baumol "acknowledge, of course, that standards auctions may not always yield results as socially desirable as those of the basic model, particularly if the number of competing IP solutions is very limited and there is incomplete information about the value of each." 32 They also acknowledge that the auction-like process may yield rewards for innovation that are appropriate from a social standpoint only if: (1) licensors cannot be approached by the SSO members collectively after their bids have been submitted to negotiate their claims downward; ${ }^{33}(2)$ the selection process is not skewed by one or more SSO members; ${ }^{34}$ and (3) licensors have the option to negotiate and contract outside the formal standard-setting process. $^{35}$ Unless all three conditions are met, Swanson/Baumol note that an auction-like process would harm innovation by creating monopsony power. ${ }^{36}$ As they observe, "In the case of the typical SSO, however, the integration and efficiencies needed to justify outright collective bargaining on royalties are in short supply." 37 Thus, instead of efficiencies, the outcome is likely to be undercompensation for innovation. We agree, and would add that even when these conditions are met, an auction-like process may still harm innovation, as we will explain below.

First let us consider each of these three conditions carefully. The first condition requires SSO members to "credibly commit" and adhere to the auction mechanism initially adopted. Full commitment is a critical assumption in auction theory; but one that does not necessarily hold in practice. Economic theory has shown that the party who designs the auction has generally the incentive to change the auction rules in the middle of the play. And in many circumstances it may also have the ability to do so. Vartianen (2005) describes the commitment problem as

\footnotetext{
${ }^{32}$ Swanson \& Baumol, supra note 2, at 21.

${ }^{33} I d$. at 17.

${ }^{34} I d$.

${ }^{35} \mathrm{Id}$.

${ }^{36} I d$.

${ }^{37}$ Id. at 13 .
} 
"pathological". ${ }^{38}$ He shows that when the parties cannot commit themselves to the auction mechanism, the English (or open ascending) auction is the only feasible procedure. In particular, the sealed-bid auction proposed by Swanson and Baumol is not feasible in the absence of commitment power. The alternative, an English auction format may, as we will see below, facilitate the adoption of collusive or predatory strategies; which could be the reason why Swanson and Baumol proposed a sealedbid auction instead.

The second condition, which assumes that the SSO voting mechanism cannot be skewed by an individual member or subset of members, also may be problematic. This follows because, in practice, some SSO members-those that are vertically integrated - are also the owners of some of the competing technologies. Hence, these vertically integrated firms will have the incentive, and sometimes also the ability, to tailor the selection mechanism in their favour. For example, they may find it easier to win the auction (bid low) and have their technologies selected to the standard because, as noted earlier, they can earn profits downstream. In fact, vertically integrated firms may forgo royalty earnings altogether in favour of downstream earnings, an option not available to non-vertically integrated firms. Even if nonintegrated IP owners do win a vote, they can only do so by bidding more aggressively in order to compensate for the bias, thus increasing the profitability of the downstream operations of the vertically integrated SSO members. ${ }^{39}$

Finally, it is not always possible for licensors to opt out of the formal standard-setting process. What are the options open to licensors that would like to "walk away"? One option might be to attempt a de facto standard, where the defecting firm would offer its proprietary solution as a competing standard over that offered by the cooperative SSO. Of course, this option only works if certain prerequisites hold. Namely, the firm must be able to offer a complete proprietary

\footnotetext{
${ }^{38}$ Hannu Vartianen, Auction Design without Commitment, (Yrjö Jahnson Foundation, Working Paper, Mar. 2005).

${ }^{39}$ See Jean Jacques Laffont \& Jean Tirole, A THEORY OF INCENTIVES IN PROCUREMENT AND

REGULATION ch. 14 (1993); Jean Jacques Laffont \& Jean Tirole, Auction Design and Favoritism, 9(1) INT'L J. Indus. ORg. 9 (1991); Fernando Branco, Procurement Favoritism and Technology Adoption (Center for Economic Policy Research, Discussion Paper 2270, 1999).
} 
solution. In many instances - especially when complex high technology products are at issue-this will not be an option at all. Many firms only hold a piece of the solution and cannot establish a de facto standard on their own. Even if they could, it would have to be clear to the potential users of the standard that the proprietary solution was either technically superior to the SSO standard or low enough in cost to offset any technical inferiority. Otherwise, the defecting firm would have little hope of winning a de facto standards battle. Absent this option, the licensor might be able to join a competing SSO. Certainly some standards do face competition from other cooperative efforts centred on different technological solutions for the same or largely similar issues, ${ }^{40}$ but this is far from the norm. Many times this option will simply not be available. ${ }^{41}$ Lastly, the firm considering defection might just abstain from participating in standard setting efforts altogether. For certain standards, this might be a viable option. For example, if the standard does not cover the firm's core technologies, but is instead peripheral to its primary commercial interests, this may be an attractive option. But for products that are core, this will not be viable at all. In many industries, not participating in the standard setting efforts can effectively shut a firm out of a market altogether. This is apparently the case for 802.11 technologies. For any firm that wants to offer products or help direct the evolution of wireless networking, participation in the IEEE standard setting efforts is mandatory. ${ }^{42}$

It is thus unrealistic to suggest that licensors disgruntled with an SSO's rules or procedures should simply leave. One must first ask whether, in the particular circumstances at hand, leaving is even an available choice. This is of great practical importance: the ability to walk away from a deal is a key determinant of a firm's

\footnotetext{
${ }^{40}$ For example, in mobile telecoms two competing standards, CDMA and GSM, compete for operator networks and, through them for end users.

${ }^{41}$ For example, in the case of $802.11 \mathrm{n}$, a standardization effort formed outside of the IEEE, known as the EWC. Though the group was comprised of vendors with "90 percent of the market" and it seemed they could proceed without the involvement of an official standard setting body, the group still pushed for the approval and involvement of the IEEE. See B. DeLacey, K. Herman, D. Kiron, \& J. Lerner, Strategic Behavior in Standard-Setting Organizations (Working Paper, 2006), available at http://papers.ssrn.com/sol3/papers.cfm?abstract id=903214

${ }^{42}$ See Thomas Eisenmann \& Lauren Braley, Atheros Communications, Harvard Business School Case Study 9-806-093, Feb. 13, 2006. The discussion of implementing 802.11 products and competing with other firms doing the same makes clear that those not involved in the IEEE standard setting process have little hope of competing effectively in this market.
} 
bargaining power. ${ }^{43}$ Such freedom indicates that the firm not locked into a particular relationship, and is instead able to make credible threats that push negotiations forward. If a firm is not able to walk away, its bargaining power is small. A licensor that faces collective action by SSO members and has no credible "outside" option will have to accept the terms imposed by the buyer cartel even if that means that its investments are under-compensated.

In sum, none of the three conditions is trivial. The model that Swanson and Baumol present is eloquent and informative, but there are reasons to believe that one or more of their three conditions may fail in any given real-world standard-setting process. Hence, there is a serious risk that the result of the auction process would lead to collective price negotiation that in turn under-compensated patent holders and reduced incentives for innovation. These are, however, not the only difficulties faced by the ex ante auction approach, as we explain in the remainder of this section.

\section{A. Alternative auction mechanisms}

If the values of the competing technologies are private information (i.e., known only to the technology holder) — as they are likely to be - the outcome of a standards auction, and consequently the use of such ex ante royalty rates as a benchmark as well, will be a function of the precise auction mechanism adopted by the SSO. As explained in detail in Klemperer (2004), ${ }^{44}$ different auction designs tend to produce different outcomes. The celebrated "revenue equivalence theorem" in auction theory states that the expected outcome of different auction mechanisms will coincide when, among others, the following assumptions hold: (a) each bidder's (privately known) valuation is independent of its competitors' private valuation and (b) bidders are symmetric (more precisely, their privately known valuations are drawn from a common distribution). ${ }^{45}$ Neither of these two assumptions is likely to hold in the standard-setting context.

\footnotetext{
${ }^{43}$ See Ken Binmore, Avner Shaked, \& John Sutton, An Outside Option Experiment, 104 Q. J. ECON. 753 (1989).

44 Paul Klemperer, Auctions: Theory and Practice (2004).

${ }^{45}$ That is, the range of possible outcomes is the same. $I d$.
} 
First, the valuations of the various IP owners whose technologies compete to be selected to the standard are likely to be correlated (or to be absolutely precise "affiliated" profitability of the downstream product or products in which its technology will be embedded if selected to the standard. It will rely on its own understanding of the market, but only to some extent. IP owners will also lean on the views of market analysts and customers. In consequence, when the value estimate of an IP owner is high, the estimated values of all other IP owners are also likely to be high. Economic theory shows that when valuations are correlated, as it is likely to be the case in SSO ex ante auctions, an open ascending auction will lead to more aggressive (lower royalty) bidding than a sealed-bid auction, potentially to the point of no longer providing coverage for that "constant stream of R\&D". 47

Second, as explained above, many standard-setting processes involve both non-integrated and vertically integrated IP owners. The valuations of these two different types of players are bound to be different. Vertically integrated companies are likely to have more precise information about the potential size and profitability of the downstream markets enabled by the standard. Furthermore, their dual role as sellers and buyers of technology dramatically affects their bidding incentives. Maskin and Riley (2000) show that when bidders' valuations are asymmetric an open ascending auction will tend to favour bidders with higher valuations, while the opposite is true with a first-price sealed-bid auction. ${ }^{48}$

In conclusion, the outcome of an SSO-sponsored auction will depend on its precise design. Which design is more efficient depends critically on fine details about the values of the technologies of the competing IP owners, which in reality will only

\footnotetext{
${ }^{46}$ To use an analogy from first semester statistics class, the two assumptions describe the process of pulling a marble from an urn, observing whether it is black or white, and then returning it to the urn. Each draw from the urn is unaffected by previous or subsequent draws and each draw has the same odds of producing a black versus a white marble. This is typically not the case with technologies in real world standards. There, some common factors affect each draw, so that the draws are no longer independent.

${ }^{47}$ Paul R. Milgrom \& Robert J. Weber, A Theory of Auctions and Competitive Bidding, 50(5) ECONOMETRICA 1089 (Sept. 1982).

${ }^{48}$ Eric S. Maskin \& John G. Riley, Asymmetric Auctions, 67(3) REv. ECON. StUD. 413 (July 2000).
} 
be imperfectly known by SSO members. This is of course troublesome: in principle, there could be as many ex ante benchmarks as possible auction processes.

Swanson and Baumol address this problem by proposing the sealed-bid auction model. This auction mechanism has many virtues. As explained in Klemperer (2002), ${ }^{49}$ a first-price sealed-bid auction discourages collusion among bidders and encourages entry. In an ascending auction, collusion is easier because bidders can use the first rounds of the auction to signal who should win and they can also detect a deviation easily due to the transparency of the auction design. Furthermore, in an open ascending auction "there is a strong presumption that the firm which values winning the most will be the eventual winner, because even if it is outbid at an early stage, it can eventually top any opposition. As a result, other firms have little incentive to enter the bidding, and may not do so if they have even modest costs of bidding". 50

However, the sealed-bid auction also has its own drawbacks. Most importantly, it may lead to inefficient outcomes: the auction need not be won by the bidder with the highest valuation (i.e., in the context of standard-setting, the IP owner with the technology that is likely to result in a wider and more profitable downstream market). ${ }^{51}$ Also, as noted above, when valuations are correlated, a first-price sealed bid auction is likely to result in higher royalty rates than an open ascending auction provided that the valuations of competing bidders are not too asymmetric. This is due to the so-called "winner's curse". As explained by Klemperer (2003), "The 'winner's curse' reflects the fact that winning an auction suggests one's opponents have pessimistic views about the value of the prize, and bidders must take this into account by bidding more conservatively than otherwise". ${ }^{52}$ The winner's curse correction is smaller in open ascending auctions because each bidder can infer the valuations of its

\footnotetext{
${ }^{49}$ Paul D. Klemperer, What Really Matters in Auction Design, 16(1) J. ECON. PerSP. 169 (2002).

${ }^{50} I d$. at 5 .

${ }^{51} \mathrm{Id}$. at 14 .

${ }^{52}$ Paul D. Klemperer, Using and Abusing Economic Theory---Lessons from Auction Design, 1(2-3) J. EUR. ECON. ASS'N 272 (2003).
} 
competitors by observing the points at which they stop bidding. ${ }^{53}$ Finally, though sealed-bid auctions make collusion and predation less likely, they do not eliminate those risks entirely.

\section{B. Asymmetric bidders}

A key assumption in the basic auction model analysed by Swanson and Baumol is that all patent owners are vertically disintegrated-i.e., they are pure innovators. In reality, however, both non-integrated firms and firms with both intellectual property and manufacturing interests compete to see their technologies adopted by SSOs. This factual discrepancy has important implications. The vertically integrated competitors may be able to win the auction sponsored by the SSO even if their technologies are less valuable than those of their non-integrated counterparts. Such vertically integrated companies not only licence to third parties, but also implicitly licence to themselves as manufacturers. This means that they simultaneously act as sellers and buyers of their own IP. Effectively, those competitors hold a stake in the prize of the auction, which in this case is the net present value of the revenues generated by the owner of the technology selected to the standard.

Economic theory predicts that holding a stake in the prize of an auction, generally referred to as a "toehold" in the literature, may have a significant impact on bidders' behaviour and hence on the results of the auction. A bidder is said to have a toehold in an auction if he owns a stake in the prize that is being auctioned. This situation arises frequently (but not exclusively) in takeover auctions, where potential bidders acquire a small stake in the target company being auctioned before the auction takes place. In the standard-setting context, a bidder will have a toehold in the auction prize if a share of the revenues generated by the owner of the technology selected to the standard corresponds to the payments made by its downstream

\footnotetext{
53 This is strictly true when the valuations of bidders are symmetric. When valuations are asymmetric, the winner's curse may aggravate the disadvantages faced by the weaker bidders (those with low valuations). In this case a sealed bid auction may perform better from the viewpoint of the SSO members.
} 
subsidiary. The effects of such toeholds have been analysed extensively in the economics literature. ${ }^{54}$

The literature has established that the presence of a toehold has two effects on bidding behaviour. ${ }^{55}$ The first is a direct effect: a toehold changes a bidder's valuation because a share of the auction prize flows back to him through his stake in the prize. In other words, having a toehold makes winning the auction more valuable so the toehold bidder can bid more aggressively. In addition, there is also an indirect effect. The existence of toeholds aggravates the risk of the winner's curse for bidders without toeholds (or with toeholds that are relatively small compared to another bidder's), making them bid even less than they otherwise would have. This is because a bidder who beats a bidder with a (larger) toehold learns that the true value of the prize has been grossly over-estimated. Conversely, the risk of the winner's curse is reduced for the bidder with the largest toehold, meaning this bidder will shade her bid less than she otherwise would have. As a result, the toehold bidder is more likely to win.

Let us illustrate the effects of such toeholds using the simple model developed by Swanson and Baumol to explain the functioning of their proposed ex ante auction. As explained above, there are two competing technologies: A and B. The owners of both technologies_-companies A and B, respectively - are vertically disintegrated, i.e., they have no toehold on the auction prize. Technology A would result in downstream production costs of 5 per unit of output, while technology B would lead to downstream production costs of 6 per unit of output. Under the assumption that licensing involves no recurring costs and that both bidders know the cost reductions that can be achieved with each technology, bidder A would win the auction commanding a license fee of 1 per unit of output.

\footnotetext{
${ }^{54}$ See, e.g., Jeremy I. Bulow, Ming Huang, \& Paul D. Klemperer, Toeholds and Takeovers, 107(3) J. Pol. ECON. 427 (1999); David Ettinger, Takeovers, Toeholds and Deterrence, (ELSE, Univ. College London, Working Paper, 2003); Sudipto Dasgupta \& Kevin Tsui, Auctions with Cross-Shareholdings, 24(1) ECON. TheORY 162 (July 2004); Sandra Betton, B. Espen Eckbo, \& Karin S. Thorburn, The Toehold Puzzle, (CEPR Discussion Paper No. 5084, May 2005), available at http://ssrn.com/abstract=776704

${ }_{55}$ Paul D. Klemperer, Auctions with Almost Common Values: The "Wallet Game" and its Applications, 42(3-5) EUR. ECON. REV. 757 (1998).
} 
Suppose instead that company B is vertically integrated and its downstream profits are $\pi(f+c)$, where $f$ is the license fee and $c$ is the production cost paid by B. Of course, B's downstream profits are greater when $f+c$ is smaller (formally, $\pi(f+c)$ is decreasing in $f+c$ or $\left.\pi^{\prime}(f+c)<0\right)$. Company $\mathrm{B}$ has a toehold in the prize of the auction: a lower license fee increases its downstream profits. This has an impact on its bidding behavior. In the basic model, with no toehold, company B was willing to lower its license fee in order to win the contest provided that it was larger than zero. This is why company A was only able to extract a license fee of 1 per unit output. With a toehold, company B's total profits when A charges 1 and B sets its fee equal to 0 are $\pi(1+5)$. Would $\mathrm{B}$ have the incentive to set a licensee fee $f<0$ in order to win the auction? Suppose it does set $f$ below 0 and wins the auction. Its total profits would be equal to $f+\pi(f+6)$. The first term, which measures B's licensing profits, is negative but the second term, which gives B's downstream profits, is greater than $\pi(1+5)$ or $\pi(6)$. Therefore, company B will prepare to bid below 0 if $\pi(f+6)-\pi(6)>-$ $f$. That is, if the loss incurred in the licensing market is more than compensated by the increase in downstream profits. It is easy to show that this will be the case provided that a reduction in the license fee has a significant positive impact on downstream profits. ${ }^{56}$ When that condition holds, B will bid below 0 and A will have to accept a licensee fee below 1 or risk losing the auction despite its technological superiority.

This is not just theory. The importance of toeholds in auctions has been documented empirically. Betton and Eckbo (2000) have shown in a sample of 1353 tender offer contests over the period 1971-1990 that greater toeholds increase the probability of success and lower the probability of rival entry into the contest. ${ }^{57}$ Likewise, Walking (1985) has also shown that bidder control of target shares prior to the offer substantially increases the probability of acquiring the desired number of additional shares. ${ }^{58}$

\footnotetext{
${ }^{56}$ Mathematically, $\pi(f+6)-\pi(6)=f \pi^{\prime}(6)$. So condition $\pi(f+6)-\pi(6)>-f$ van be rewritten as $\pi^{\prime}(6)<-$ 1 or $\left|\pi^{\prime}(6)\right|>1$, where $|\cdot|$ indicates absolute values.

${ }^{57}$ Sandra Betton \& B. Espen Eckbo, Toeholds, Bid-Jumps and Expected Payoffs in Takeovers, 13(4) REV. FIN. STUD. 841 (2000).

${ }^{58}$ Ralph A. Walking, Predicting Tender Offer Success: A Logistic Analysis, 20(4) J. Fin. \& QuANTITATIVE ANALYSIS 461(Dec. 1985).
} 
In conclusion, in a standard-setting context, the dual role of vertically integrated companies in the standard setting process - innovators and users-would place them at a competitive advantage in any ex ante auction. They can offer attractive licensing terms because of their downstream profits. In consequence, SSOs operating auctions like those proposed by Swanson and Baumol may select the technologies owned by vertically integrated companies even if those technologies are not the most efficient. Non-integrated companies may have to bid very low to match the terms offered by their vertically integrated counterparts, which may reduce their incentives to innovate and participate in the cooperative standardization process. Non-integrated companies may even be forced out of the relevant innovation market.

\section{Multi-dimensional auctions}

One of the most significant obstacles in applying ex-ante auctions to standard setting lies in the nature of the product being auctioned. The objects of an SSO auction are complex technologies with multiple characteristics. SSO members are typically concerned not only with the level of the royalty rate the owner of a patent asks for, but also frequently care about a range of quality parameters associated with the patented technology. Such parameters might include the ease or cost with which the technology can be implemented, the performance or processing speed, the degree of interoperability with other components, or the technical reliability. The members of an SSO will evaluate not only the financial terms of the bids from different IP holders, but also the relevant quality parameters of the respective bids. Alternative technologies will compete not only on pre-committed royalty rates, but also on the various technical benefits from using one technology rather than the alternatives.

Economic theory shows that it is very difficult to design an auction which leads to the most efficient outcome when the subject of the auction involves multiple dimensions. For example, Dasgupta and Maskin (2000) show that when bidders' characteristics are multi-dimensional there is no efficient auction where bidders compete in price only. ${ }^{59}$ Manelli and Vincent (1995) provide a good illustration of

${ }^{59}$ Partha Dasgupta \& Eric Maskin Efficient Auctions, 115(2) Q. J. ECON. 341 (May, 2000). 
that general result. They consider an economic scenario in which a buyer (the SSO in the standard setting context) faces a number of potential sellers (technology owners) who are privately informed about the "quality" of their products (technologies). ${ }^{60}$ Increasing quality is costly. Manelli and Vincent show that an auction where sellers bid on price only may be very inefficient. The reason is that a simple auction of that sort will allocate the trade to the bidder or bidders offering the lowest prices (will select the technology of the IP owner quoting lower royalty terms). But in their setting a low bid is associated with a product of low quality. They show that the winning bid converges to the lowest possible quality level when the number of sellers increases, and that this is unambiguously suboptimal when the contribution of quality to social surplus is large enough. Finally, they also demonstrate that sequential bargaining may yield results which are superior from a social viewpoint than those of an auction.

In practice, a number of different methods have been employed to deal with this problem as effectively as possible. For instance, procurers frequently rely on detailed request-for-quotes (RFQ) that specify minimum standards that a bidder must satisfy so that they can evaluate the bids on price only. In other cases, the buyer of a service might pre-select a small number of bidders and then negotiate on all dimensions of the service with each of them. It seems unlikely that either of these approaches would offer an efficient way to deal with auctions over a standard.

Scholars, likewise, have devised methods for multi-dimensional auctionswhere bidders not only quote prices but also compete on non-price dimensions-but they too present some problems. One such method is something referred to as the "scoring function". According to this proposal, the most straightforward way to evaluate multi-dimensional bids is to assign a score to each price/quantity combination and to rank the bids according to their scores. Applying a scoring function effectively reduces a multi-dimensional auction to a one-dimensional auction. However, it is crucial to choose a scoring function that sets the right

${ }^{60}$ Alejandro Manelli \& Daniel R. Vincent, Optimal Procurement Mechanisms, 63(3) ECONOMETRICA 591 (1995). 
incentives. $^{61}$ Some commentators argue, for instance, that the choice of an inappropriate scoring function led to inefficient bidding behaviour in the Biennial Resource Planning Update (BRPU) auctions held in 1993 in the Californian electricity market. ${ }^{62}$ The score function was a naïve linear function of the two components of the bids, capacity and energy provision, which had an adverse incentive effect on bidders in that their bids deviated enormously from actual marginal costs.

Another solution suggested in the literature is a two stage auction meant to split the various dimensions apart. In the first stage, the firm/bidder is chosen by an auction; in the second stage bargaining over product specifications take place. The literature shows that this auction form is superior to a single stage auction (possibly with a scoring function) when bidders' valuations are correlated. ${ }^{63}$ However, bargaining over quality in the second stage might not be feasible in the context of a SSO. Efficient bargaining requires that the buyers (the SSO members) be informed about the quality parameters of the losing bidders, allowing efficient negotiations with the winning bidder about the optimal product specifications. In the context of IP rights, the competing technologies are likely to be complex and different in nature, and the members might fail to negotiate efficiently with the patent holder. ${ }^{64}$

The model of an ex ante auction in Swanson and Baumol works well because it concerns process innovations-i.e., technologies that facilitate reductions in the unit costs of production. This makes it simple to construct an additive scoring function: $f_{i}+c_{i}$, where $f_{i}$ is the license fee offered by IP owner $i$ and $c_{i}$ is the unit cost of production when technology $i$ is adopted. The winner in the auction is the one with the lowest score. Matters become much more complicated when the standard is

\footnotetext{
${ }^{61}$ Yeon-Koo Che, Design Competition through Multidimensional Auctions, 24(4) RAND J. ECON. 668 (1993).

${ }^{62}$ See James B. Bushnell \& Shmuel S. Oren, Bidder Cost Revelation in Electric Power Auctions, 6(1) J. Regulatory ECON. 5 (Feb. 1994); Paul Gribik, Learning from California's QF Auction, Public Utilities Fortnightly, Apr. 15, 1995; Hung-po Chao \& Robert Wilson, Multi-Dimensional Procurement Auctions for Power Reserves: Robust Incentive-Compatible Scoring and Settlement Rules, 22(2) J. REGULATORY ECON. 161 (2002).

${ }^{63}$ Fernando Branco, The Design of Multidimensional Auctions, 28(1) RAND J. ECON. 63 (1997). ${ }^{64} I d$.
} 
concerned with product innovations-i.e., when technologies differ on quality dimensions which cannot be easily translated into price (license fee) equivalents.

\section{Complementary patents}

Another key feature of standard setting is that standards typically comprise multiple innovations, which are often protected by patents. ${ }^{65}$ For example, the WCDMA air interface standard - a protocol to enable communication between mobile handsets and base stations - involves many patented innovations in the area of mobile communications. ${ }^{66}$ Some of the patents in a standard are regarded "essential" to the standard. ${ }^{67}$ From the viewpoint of a manufacturer that intends to develop and commercialise a product that is compliant with a standard incorporating multiple essential patents, all those patents are strict complements: the company needs to obtain licenses for each of them in order to avoid the risk of legal damages and abrupt termination of business. In many standards the ownership of the essential patent rights is fragmented: no legal entity has all the rights necessary. ${ }^{68}$ This is the case of the WCDMA standard where Ericsson, Nokia, Qualcomm and several others declare to hold patents that are essential to the standard.

The existence of multiple, complementary patents may not pose a problem in some simple scenarios. For example, Layne-Farrar et al. (2006) have extended the simple auction model in Swanson and Baumol (2005) to deal with multiple complementarity patents. These authors find that patents covering "essential" technologies with a greater contribution to the value of the standard and without close substitutes before the standard gets adopted should receive higher royalty

\footnotetext{
${ }^{65}$ See Mark A. Lemley, Intellectual Property Rights and Standard Setting Organisations, 90 CAL. L. REV. 1889 (2002) and references therein.

${ }^{66}$ See Dave Mock, The Qualcomm Equation: How a Fledgling Telecom Company Forged a New Path to Big Profits AND Market Dominance (2005).

${ }^{67}$ The European Telecommunications Standards Institute (ETSI) has defined essential patents as those patents for which "... it is not possible on technical (but not commercial) grounds, taking into account normal technical practice and the state of the art generally available at the time of standardization, to make, sell, lease, otherwise dispose of, repair, use or operate equipment or methods which comply with a standard without infringing that intellectual property right." See "ETSI Intellectual Property Rights Policy", available at http://www.etsi.org/legal/home.htm.

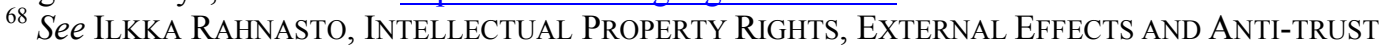
LAW, LEVERAGING IPRs IN THE COMMUNICATIONS INDUSTRY (2003).
} 
payments after the adoption of the standard. ${ }^{69}$ However, their model, as the original model developed by Swanson and Baumol, assumes that at the ex ante stage there is no uncertainty with respect to which patents are relevant to the standard. This may not be always realistic, which may affect the performance of the ex ante auction in ways that are difficult to predict: Since the patents comprising a standard are complementary, the bidding behaviour of suppliers of one capability will depend on the outcome in an auction of another capability and/or on the emergence of new patents/technologies later on that will enhance the value of the standard. When the set of essential patents is known and stable, the interconnection between the various auctions need not be problematic. But when it is not, then the auction outcome may be hard to predict.

\section{E. Uncertainty}

Yet another practical complication in applying auctions to standard setting is that most standards entail a high degree of uncertainty during their development, which could lead to strong incentives to renegotiate ex post. ${ }^{70}$ At early stages of negotiations on a standard, uncertainty will run high over which IP will be included and which technological path will be followed. During the development process, some new and superior complementary IP could arise, or the mix of patents might be different than expected at the outset. Whenever agents receive new information, though, they may want to renegotiate licensing terms agreed to before. Of course, as long as one party insists on the original contract such renegotiation is blocked, but if both parties find it profitable to renegotiate no-one can prevent them from cancelling

\footnotetext{
${ }^{69}$ Anne Layne-Farrar et al., supra note 2.

${ }^{70}$ Renegotiation is extensively discussed in the field of contract theory. There is usually scope for renegotiation when a contract does not cover all future eventualities (incomplete contracts). See for a general textbook on contract theory: PATRICK BOLTON \& MATHIAS DEWATRIPONT, CONTRACT THEORY (2005). Examples of high-level contributions to this field which highlighted the impact of renegotiation on the initial contract design include: Oliver D Hart \& John Moore, Incomplete Contracts and Renegotiation, 56(4) ECONOMETRICA 755 (1988); Eric Maskin \& John Moore, Implementation and Renegotiation, 66(1) REV. ECON. STUD. 39 (1999); and Philippe Aghion, Mathis Dewatripont, \& Patrick Rey, Renegotiation Design with Unverifiable Information, 62(2) ECONOMETRICA 257 (1994).
} 
a contract or deal to agree on more favourable terms. Thus, choosing when an auction is held would be critical to limiting any wasteful renegotiations.

\section{F. The risk of under-compensation}

Because of all these problems and shortcomings, the adoption of an ex ante auction may result in serious under-compensation of productive investment and innovation. This should be a matter of great concern for regulators and antitrust authorities. As stated by Swanson and Baumol, "Careful attention must be paid to the risk that the policies and practices adopted by SSOs and the actions taken by the participating members in the course of the standard-setting process may yield rewards for innovation that are too low by comparison to the level of incentives normally entailed by the intellectual property laws and accepted by the antitrust laws". 71

Note first of all that even in the simple model developed by Swanson and Baumol, where none of the problems listed above applies, the payment received by the winner of the ex ante auction - company A-may not be enough to properly compensate the investment costs incurred in developing its superior technology. Indeed, company A receives a payment equal to the incremental value of its technology relative to the next best option. It will receive that payment for as long as the standard relies on its technology and its patent does not expire. It should be clear that such an amount may or may not exceed its R\&D costs (plus an adequate rate of return which takes into account the risky nature of its investment). Consequently, even in the basic setting analysed by Swanson and Baumol the ex ante auction may over- or under-compensate innovation. But under-compensation is more likely when alternative technologies are close substitutes, which are precisely the cases where an ex ante auction makes most sense.

The under-compensation risk becomes more serious and troublesome when the assumptions of the basic Swanson and Baumol model fail to hold. Undercompensation is a serious risk when the ex ante auction degenerates in a buyers'

${ }^{71}$ Swanson \& Baumol, supra note 2, at 13. 
cartel, which we saw could happen in the standard setting context. But it is likely to be a problem even if there is no coordination amongst SSO members: as we saw above, pure innovators may have to bid very low to win over their vertically integrated competitors.

This risk has been denied by Skitol (2005). ${ }^{72}$ Skitol maintains that "Information technology standard setting processes are one context in which carefully structured concerted buyer power could be pro-competitive". ${ }^{73} \mathrm{He}$ advocates an approach under which SSOs could "require, or at least affirmatively acknowledge, 'ex ante' disclosure of intended license terms to voting, with a related mechanism for collective negotiation of the license agreement." $" 74$ He claims that joint negotiations will not lead to "infracompetitive" licensing terms unless "the buying side of the SSO process possesses real 'monopsony' power"-i.e., "it encompasses most, if not all, of the expected market demand for the patent owner's technology ... Particularly, if the same buying group is expected to retain the same power over successive generations of the technology space in question ..." If such monopsony power exist, "there could then be a resulting anticompetitive disincentive to investment in further innovation". 75

We have two comments. First, the possibility of monopsony power should not be underestimated. As explained above, licensors will often be unable to opt out of formal SSO processes: there may not be competing SSOs available, de facto standardization may not represent a feasible option, and there may be no commercially viable future for technologies which do not become an industry standard. In those cases, as Skitol recognises, collective negotiation of the licensing terms would result in under-compensation ("infracompetitive" prices) and underinvestment. Second, contrary to what Skitol claims, collective negotiation may also lead to underinvestment in R\&D when the buying side of the SSO process does

\footnotetext{
${ }^{72}$ Skitol, supra note 11.

${ }^{73} \mathrm{Id}$. at 728 .

${ }^{74} \mathrm{Id}$. at 729. Emphasis added.

${ }^{75} \mathrm{Id}$. at $740-741$.
} 
not encompass most of the expected market demand for the patent owner's technology.

Let us explain why. It is well-known that the outcome of a negotiation depends on the "exit options" available to each of the parties in the negotiation. A party with more (and more attractive) options can negotiate a better deal. ${ }^{76}$ It is also known that legal rules can affect the exit options opened to the bargaining parties and, hence, modify the distribution of the gains for trade. ${ }^{77}$ Consider, for example, that companies A and B need to license company C's patented technology to lawfully develop and commercialise their products. Alternatively, they could use the technology developed by company $\mathrm{D}$, which is however regarded as relatively inferior. Suppose further that joint licensing negotiations are prohibited so that when patent owner C negotiates with company A (resp., company B), it has the option to exit and deal with B (resp., A) only when A (resp., B) refuses to negotiate in good faith. Likewise, companies A and B have an outside option when negotiating with $\mathrm{C}$ : company D. Suppose instead that joint negotiations are lawful so that companies A and $\mathrm{B}$ negotiate jointly with company $\mathrm{C}$. In this scenario, company $\mathrm{C}$ has no exit options, while companies A and B can still use technology D as an outside option in their joint negotiations with C. Compared with the scenario where joint negotiations are unlawful, company $\mathrm{C}$ will no longer be able to walk away if company $\mathrm{A}$ (and/or B) refuses to negotiate in good faith. As a result, the rents obtained when joint negotiations are possible may be below those it would receive under the SwansonBaumol ex ante auction.

\section{IV.SIMULATING EX ANTE AUCTIONS}

Swanson and Baumol (2005) call only for an "auction-like process" to determine prices ex ante; an actual auction is not necessary. In late 2006 two SSOs

\footnotetext{
${ }^{76}$ Binmore, Shaked, \& Sutton, supra note 43.

${ }^{77}$ Douglas G. Baird, Robert H. Gertner, \& Randall C. Picker, Game Theory And the LaW (1998).
} 
claiming particular concerns about ex post opportunism approached the U.S. Department of Justice for Business Letter Reviews of just such auction-like processes implemented through their respective Intellectual Property Rights policies.

The VMEbus International Trade Association (VITA) was the first to take this step. VITA's standard setting arm, VSO, now requires the upfront disclosure of patents and patent licensing terms in connection with all VMEbus standard-setting activities. Each VSO member must, among other things, declare the maximum royalty rate for all the patent claims that it represents, owns, or controls and that may become essential to implement the standard in question. The most restrictive nonroyalty terms must also be disclosed, with all declarations "irrevocable", even though patent holders may submit later declarations with even less restrictive licensing terms (including lower royalties). With such a policy in place, the member votes for standard specifications can be interpreted as an auction. The members will be voting with both technology and price in mind, and the winners of the vote will be incorporated into the standard at their promised licensing terms. The Department of Justice stated that it did not intend to challenge the proposed policy unless the change proved anticompetitive in practice. ${ }^{78}$

The VSO is properly cognizant of the potential for cartel outcomes with ex ante disclosure. The policy is therefore careful to state that any joint discussion of terms within the SSO is prohibited. The declarations should form the upper bound, but all specific licenses must then be negotiated bilaterally and confidentially. It remains to be seen whether the policy will work as planned, though, with terms disclosed ex ante, used for specification determination, but not discussed at any SSO meetings.

\footnotetext{
${ }^{78}$ Business Review Letter from Hon. Thomas Barnett to Robert Skitol, Esq. (Oct. 30, 2006), available at http://www.usdoj.gov/atr/public/busreview/219380.htm.
} 
The IEEE (Institute for Electrical and Electronics Engineers) has a Business Letter Review for similar IP policy changes still pending before the DOJ. ${ }^{79}$ It is quite similar to the VITA policy, except in one important respect. ${ }^{80}$ Specifically, in contrast to the express and unambiguous prohibition in the VITA policy against discussions among multiple prospective licensees of disclosed rates and terms, the IEEE policy explicitly permits and encourages such discussions. ${ }^{81}$

As discussed at length above, just like formal auctions these auction-like processes with ex ante term disclosure are at risk for under-compensating innovations (especially with the IEEE proposed policy change, given the endorsement of collective bargaining). In fact, both processes are likely to produce outcomes which coincide with those of a plain ex ante auction. To see this consider again the simple model developed by Swanson and Baumol (see Section II above), where two technologies $\mathrm{A}$ and $\mathrm{B}$ compete for selection to the standard, and technology $\mathrm{A}$ is superior to technology $\mathrm{B}$ in that it achieves a greater reduction in unit production costs. Suppose now that both IP holders are required to disclose a maximum royalty rate ex ante, that the disclosed terms represent an irrevocable commitment, and that the maximum disclosed terms are relied upon in the selection process. Technology A will be selected only if its technological advantage is not offset by a higher disclosed maximum royalty rate. If company $\mathrm{A}$ is rational and considers that company $\mathrm{B}$ is also likely to act rationally, it will anticipate that B will be prepared to set a very low maximum royalty rate, potentially as low as 0 . Consequently, in order to be selected

\footnotetext{
${ }^{79}$ Letter from Michael A. Lindsay, on behalf of IEEE-SA, to the DOJ, addressed to the Honourable Thomas Barnett, (Nov. 29, 2006).

${ }^{80}$ In addition, rather than make the maximum royalty rate and most restrictive terms mandatory for all members, the IEEE claims that it is simply encouraging members to make such declarations. The mandatory-voluntary distinction is unlikely to make any difference in practice, however, if the consequence of nondisclosure is a refusal to consider for inclusion in a standard specification a technology for which no disclosure has occurred. .

${ }^{81}$ See Section 5383 of the IEEE-SA Standards Operation Manual, which expressly permits the discussion by working group participants to discuss "relevant costs," which may "include any potentially Essential Patent Claims." See also Slide no. 5 of the IEEE PatCom Instructions to Working Group Chairs, instructing that "[r]elative costs, including license costs of essential patent claims of different technical approaches may be discussed." In addition, the IEEE-SA Antitrust Policy is under revision to expressly permit the discussion of licensing costs as part of discussions of relative costs, directly within working group meetings.
} 
with certainty, the maximum royalty rate that company A can charge is equal to 1 , exactly as in the Swanson and Baumol model. Any higher rate could trigger the selection of technology B.

The structure of disclosure reinforces this dynamic: maximum terms are offered first and subsequent disclosures can only offer better terms, which provides increased pressure on lowering licensing fees to "win" inclusion in a standard. This is, of course, the outcome desired by both the VITA and IEEE because of stated concerns over the perceived abuse of ex post market power. For example, VITA noted in its letter to the DOJ that "excessive license demands can stall implementation of a final standard", but the specific instances it listed as support for this point all appear to concern a lack of adequate patent disclosure, not unreasonably high terms. ${ }^{82}$ The IEEE concerns are even less specific and appear aimed at the mere possibility for ex post abuse, not an actual history of it. ${ }^{83}$

At the risk of being redundant, the problem with using ex ante auctions to correct for these perceived problems is the very real risk of under-compensation. When weighed against the potential risk of ex post market power abuse, these policy changes appear to us to go too far. Member firms concerned about inadequate remuneration for their risky innovation investments are likely to be concerned about the changes in SSO disclosure policy as well. In fact, the VSO has already lost one member due to the IP policy change: Motorola has reportedly left the SSO as a result of the new term disclosure rules.

\footnotetext{
${ }^{82}$ The DOJ's Business Review letter merely says that VITA faces royalties "higher than expected". See Letter from Robert Skitol, on behalf of VITA, to the DOJ, addressed to the Honourable Thomas Barnett, p. 4.

83 "The difficulty with the current policy is that a RAND commitment is inherently vague. It can lead to expensive litigation whose cost and risk can impede the adoption of a socially valuable standard. Even where a license negotiation does not result in litigation, the ex post negotiation of license terms (that is, negotiations occurring after a technology's inclusion in a standard has increased the patentholder's market power, potentially to the point of monopoly) can lead to higher royalty payments and ultimately higher prices to consumers." See Letter from Michael A. Lindsay, supra note 79, at 3.
} 


\section{WHITHER RAND COMMITMENTS?}

Swanson and Baumol (2005) proposed a solution to the potential for ex post market power for technologies selected by standard-setting organisations: ex ante auctions sponsored by SSOs. The intuitive appeal of an ex ante auction is clear, assuming that ex post bargaining power is a problem to be solved, an assumption that may be invalid. Unfortunately, there are several reasons why SSO auctions are unlikely to deliver efficient outcomes in practice. This paper has explained them in detail.

In a nutshell, Swanson and Baumol showed that an ex ante auction would produce outcomes which are different from those of a joint buyer cartel if three assumptions were satisfied. We have explained why those assumptions are unlikely to be met in many standard-setting processes. In these cases, the ex ante auction will degenerate into a buyers' cartel. We have also shown that ex ante auctions are problematic even when those three assumptions hold. This is because SSO auctions will be characterised by incomplete information, asymmetric bidders, and multidimensional offerings. In particular, in many of those auctions, non-integrated bidders would compete with vertically integrated IP owners. We have shown that an ex ante auction design which works well when competing IP owners are all vertically integrated or all non-integrated, would not do so when there is heterogeneity among bidders. In that last case, vertically integrated bidders are likely to win the auction and/or force the non-integrated IP owners to bid very low in order to succeed. This would result in under-compensated pure innovators, reduced innovation and consumer harm.

The first and most obvious implication of our analysis is that the ex ante auction approach cannot be relied on to interpret RAND commitments in all circumstances. In many cases, as for example when technology owners differ with respect to their degree of vertical integration, these auctions are likely to undercompensate innovation to the ultimate detriment of consumers. This does not imply that ex ante market outcomes do not provide useful information in those cases. Our 
proposal is to use it to construct a "sufficiency test" (i.e., to define a safe harbour): evidence that ex post and ex ante licensing terms coincide would be sufficient though not necessary to establish compliance for RAND purposes.

The absence of a precise, unambiguous test (that is, a test specifying necessary and sufficient conditions) may be regarded as undesirable and seen with apprehension. First, as explained by Lichtman (2007), ${ }^{84}$ it is precisely its vagueness what makes RAND commitments such a powerful ex ante mechanism. Imprecise RAND commitments promote competition among the implementers of a standard. Actual negotiations take place bilaterally and confidentially, with public knowledge of the license offer no more specific than that it will be reasonable and fair. Each firm seeking a license has therefore strong incentives to negotiate the best terms it can win from the patent holder, so that its downstream operations acquire a competitive edge compared to other implementers. The RAND commitment then provides a backstop for this competitive process, enabling licensees to bring private lawsuits in the event that a patent holder is perceived as violating the commitment. With the threat of court imposed royalty terms (likely to be stringent, just as the US Federal Trade Commission imposed in the recent Rambus case ${ }^{85}$ ), patent holders have strong incentives to live up to their RAND commitment. When viewed in this light, a vague RAND commitment can be seen as fostering competition, contrary to the claims of ex ante auction proponents. ${ }^{86}$

\footnotetext{
${ }^{84}$ Professor Doug Lichtman made this argument at a conference held in New York City, Mar. 14, 2007. His presentation is available at $\mathrm{http}: / / \mathrm{www}$. lecgcp.com/us/events/index.aspx?id=9.

${ }^{85}$ In the Matter of Rambus, Inc., FTC Docket No. 9302.

${ }^{86}$ This argument constitutes an application to standard setting of the ideas developed in Oliver Hart \& Jean Tirole, Vertical Integration and Market Foreclosure (MIT, Department of Economics, Working papers 548, 1990); Oliver Hart \& Jean Tirole, Contract Renegotiation and Coasian Dynamics, 55(4) Rev. Econ. Stud. 509 (1988); and Patrick Rey \& Jean Tirole, A Primer on Foreclosure, in Mark Amstrong and Robert Porter (eds.) HANDBOOK OF INDUSTRIAL ORGANISATION, vol 3, forthcoming, 2007. These authors show that an upstream monopolist may not be able to extract all downstream rents when negotiations with its customers and bilateral and confidential and it is unable to commit to non-discriminatory wholesale prices. It is precisely for this reason that a vague RAND commitment is likely to lead to low royalty rates. In their models, the upstream monopolist will be able to exercise its market power without restrictions if it becomes vertically integrated or has access to a commitment device.
} 
Second, "it is entirely possible that after selection, alternative technologies (or even alternative standards) may remain viable substitutes for the standard technology", ${ }^{87}$ which eliminates the risk of ex post opportunism. Third, there are several other reasons why the owners of technologies selected to a standard may not be able to exercise market power ex post. Regardless of whether the patented technology faces viable substitutes, their licensing prices are constrained by the prices commanded by complementary patents within the standard. As noted by Swanson and Baumol, "much technology involves large amounts of intellectual property owned by many different firms, so a potential opportunist may place little weight on such freedom, recognizing that misbehavior only invites revenge by the proprietors of other essential IP rights who can wield them to block the activities of the hold out firm!" 88 That is, patent prices are limited by their context. In addition, patent holders without any downstream operations (upstream firms) are constrained by the elasticity of demand for the product in the end market. While vertically integrated firms can have incentives to raise rival downstream firms' prices through their licensing terms, they may also be open to cross licensing agreements with other integrated companies, which can hold down royalty rates as well. And lastly, all firms face dynamic constraints through the formal standard setting process. Because standards evolve over time, and many high technology standards pass through multiple versions - mobile telecom is on its "third generation" (3G) currently, with 3.5G, 4G, and "beyond 4G" already under development - any unreasonable pricing or abuse of market power can be punished in future iterations of the standard. ${ }^{89}$

\footnotetext{
${ }^{87}$ Swanson \& Baumol, supra note 2, at 10.

${ }^{88}$ Swanson \& Baumol, supra note 2, at 49.

${ }^{89}$ See DeLacey, et al., supra note 41; Joseph Farrell \& Garth Saloner, Standardization, Compatibility, and Innovation, 16 RAND J. ECON. 70 (Spring 1985); Michael Katz \& Carl Shapiro, Technology Adoption in the Presence of Network Externalities, 94 J. POL. ECON. 822 (1986).
} 


\section{CEMFI WORKING PAPERS}

0501 Claudio Michelacci and Vincenzo Quadrini. "Borrowing from employees: Wage dynamics with financial constraints".

0502 Gerard Llobet and Javier Suarez. "Financing and the protection of innovators".

0503 Juan-José Ganuza and José S. Penalva: "On information and competition in private value auctions".

0504 Rafael Repullo: "Liquidity, risk-taking, and the lender of last resort".

0505 Marta González and Josep Pijoan-Mas: "The flat tax reform: A general equilibrium evaluation for Spain".

0506 Claudio Michelacci and Olmo Silva: "Why so many local entrepreneurs?".

0507 Manuel Arellano and Jinyong Hahn: "Understanding bias in nonlinear panel models: Some recent developments".

0508 Aleix Calveras, Juan-José Ganuza and Gerard Llobet. "Regulation and opportunism: How much activism do we need?".

0509 Ángel León, Javier Mencía and Enrique Sentana: "Parametric properties of semi-nonparametric distributions, with applications to option valuation".

0601 Beatriz Domínguez, Juan José Ganuza and Gerard Llobet. "R\&D in the pharmaceutical industry: a world of small innovations".

0602 Guillermo Caruana and Liran Einav. "Production targets".

0603 Jose Ceron and Javier Suarez. "Hot and cold housing markets: International evidence".

0604 Gerard Llobet and Michael Manove: "Network size and network capture".

0605 Abel Elizalde: "Credit risk models I: Default correlation in intensity models".

0606 Abel Elizalde: "Credit risk models II: Structural models".

0607 Abel Elizalde: "Credit risk models III: Reconciliation reduced - structural models".

0608 Abel Elizalde: "Credit risk models IV: Understanding and pricing CDOs".

0609 Gema Zamarro: "Accounting for heterogeneous returns in sequential schooling decisions".

0610 Max Bruche: "Estimating structural models of corporate bond prices".

0611 Javier Diaz-Giménez and Josep Pijoan-Mas: "Flat tax reforms in the U.S.: A boon for the income poor".

0612 Max Bruche and Carlos González-Aguado: "Recovery rates, default probabilities and the credit cycle".

0613 Manuel Arellano and Jinyong Hahn: "A likelihood-based approximate solution to the incidental parameter problem in dynamic nonlinear models with multiple effects".

0614 Manuel Arellano and Stéphane Bonhomme: "Robust priors in nonlinear panel data models".

0615 Laura Crespo: "Caring for parents and employment status of European mid-life women".

0701 Damien Geradin, Anne Layne-Farrar and A. Jorge Padilla: "Royalty stacking in high tech industries: separating myth from reality". 
0702 Anne Layne-Farrar, A. Jorge Padilla and Richard Schmalensee: "Pricing patents for licensing in standard setting organizations: Making sense of FRAND commitments".

0703 Damien Geradin, Anne Layne-Farrar and A. Jorge Padilla: "The ex ante auction model for the control of market power in standard setting organizations". 